\title{
КУПРІЙ ТЕТЯНА,
}

кандидат історичних наук, доиент,

Київський університет імені Бориса Грінченка

\section{УСПІХИ ТА ПРОБЛЕМИ "ПЕРЕВИХОВАННЯ": ДО 70-ї РІЧНИЦІ ЗАВЕРШЕННЯ ДЕНАЦИФІКАЦІЇ НІМЕЧЧИНИ}

\begin{abstract}
У статті висвітлено механізми поступової демократизації німецького повоєнного суспільства, успіхи та невдачі в її реалізації. Проаналізовано соціальні аспекти політики денацифікації як процесу ідеологічної трансформації нації. Досліджено чинники впливу на формування нової соціокультурної реальності повоєнної Німеччини. При використанні даних крос-культурних досліджень відображено цілісну соціальну систему нової постнаціоналсоціалістської західноєвропейської країни в умовах окупації.
\end{abstract}

Ключові слова: денацифрікація; "очищення"; нацизм; окупаційна влада; Контрольна рада союзників.

Постановка проблеми та стан її вивчення. У цьому році минає 70 років відтоді, коли одна з найпотужніших країн світу, наскрізь пронизана нацистською ідеологією, розпочала новий етап свого існування. Для України досвід Німеччини, яка пройшла пекельні жорна денацифрікації як процесу перевиховання, є неоціненним та корисним до впровадження, оскільки, незважаючи на десятиліття, що нас від'єднують від процесів, які відбувалися в Німеччині, актуальність ідеологічного очищення не втрачає своєї сили.

У науковій літературі існують полярні оцінки денацифрікації: одні дослідники вважають ії повним провалом, інші, навпаки, безумовним успіхом. Але жоден із дослідників не ставив під сумнів аргументацію мети й цілей денацифрікації. Наукові розробки німецьких дослідників (А. Шилдта, Х. Шульце [1948], Д. Франка [1980], Й. Хайдекера, Й. Лєєба [1979], Л. Ніетгаммера, А. Боргштедт), британських та американських (Т. Войта [2000], Й. Доббінса [2008] та Е. Девідсона [1959]), радянських та пострадянських (Г. Куна [2007], Г. Почепцова [2015], В. Космача [2017], А. Борозняка, І. Бондар [2017], О. Іванова [2018]) не лише розкривають різні аспекти політики союзників щодо очищення німецького суспільства від націонал-соціалізму, а й свідчать про постійний дослідницький інтерес до цієї проблеми. В останнє десятиліття у світлі активізації правих рухів у світі І. Сиваченко [2010], М. Бойко [2018], О. Жаронкіна [2015] провели розвідки та ввели в науковий обіг кілька невідомих історичних джерел, а також на підставі наведених у часописах, документах, газетах статистичних даних та фрактів поглибили результати розробки цієї проблеми. Разом із тим, питання соціального та культурного складника політики денацифікації в повоєнній Німеччині $є$ недостатньо розкритими.

Метою статті $\epsilon$ дослідження впливу демократичних інструментів на незворотню імплементацію політики денацифікації в Німеччині в перші повоєнні роки.

Виклад основного матеріалу. 3 метою перебудови підґрунтя політичної культури в час тотальної ідеологічної катастрофи в Німеччині 1945 року почали впроваджуватися та реалізовуватися елементи денацифікації. Перевиховання було основою політики безпеки союз- ників, тому передбачало заходи суворого контролю над соціальним життям німців, у тому числі усунення нацистів з органів державної влади, освіти та всього суспільного життя. Інформаційна й віртуальна системи, хоч і під контролем людей з автоматами, але успішно трансформувалися під впливом системи фізичної. Можна зазначити, що в цих гуманітарних операціях одночасно був і примус до заданих новою владою трансформацій, що закладалися, і ефективний механізм реалізації нової політики. Із цього приводу політолог К. Васмунд писав: "Денацифікація і перевиховання (Umerziehung), за початковим задумом союзників, мають такий самий тісний взаємозв'язок, як поршень і циліндр машини. Задум передбачав виховання або перевиховання дорослих, а особливо дітей і молоді в затятих демократів за допомогою надійних, політично бездоганних німців, церкви, преси, радіо, кіно" [цит. за: Кун, 2007: 44].

Процес денацифікації проводився в декілька етапів. Після завершення початкового етапу післявоєнної трансформації Німеччини директиви Контрольної ради союзників у березні та жовтні 1946 р. заклали основи соціальної компоненти політики денацифікації. Остання увійшла в історію як "Закон № 104" й ознаменувала початок другого етапу подолання нацизму. У преамбулі до нього проголошувалося: "Закон передає справу денацифрікації повністю в німецькі руки і в своїй основі $\epsilon$ політичним законом з основоположним значенням... з метою заміни тимчасових заходів остаточним політичним очищенням" [Цит. за: Schullze, 1948]. Цікавим $€$ те, що мета політики денацифікації полягала не в покаранні, а в реінтеграції, одночасно закладалася основа процедури їі досягнення - презумпція вини кожного дорослого (понад 18 років) жителя Німеччини. Це, ймовірно, пояснюється унікальністю завдання щодо перевиховання всього населення окремої країни, що вимагала абсолютно неординарного рішення.

Превентивні заходи денацифікації розпочалися 3 оприлюднення Директиви JCS 1067 від 26 квітня 1945 р. Перші нормативні акти мали повернути Німеччину у безпекову зону, не допустити в подальшому злочини проти людства та не породити тих, хто міг би повторно 
розв'язати трагедію світового масштабу. Реконструкція суспільного життя на демократичній і мирній основі мала відбутися, навіть якби самі німці не доклали до цього значних зусиль. Отже, у Німеччині поступово формувався курс на "очищення", "переорієнтацію" на іншу модель суспільного розвитку.

У квітні 1945 р., ураховуючи "презумпцію вини" кожного німця, старшого за 18 років, у деяких містах і селах перевиховання розпочалося з шокової терапії: населення примушували оглядати концтабір в їхній місцевості й особисто брати участь у перепохованні в'язнів. Також окупаційна влада вважала, що жінки в межах такої денацифікованої повинності зобов'язані відпрацювати не менше 5 робочих днів, чоловіки - 10. Найбільш отруєні гітлерівською пропагандою знаходилися на перепохованні місяць-два.

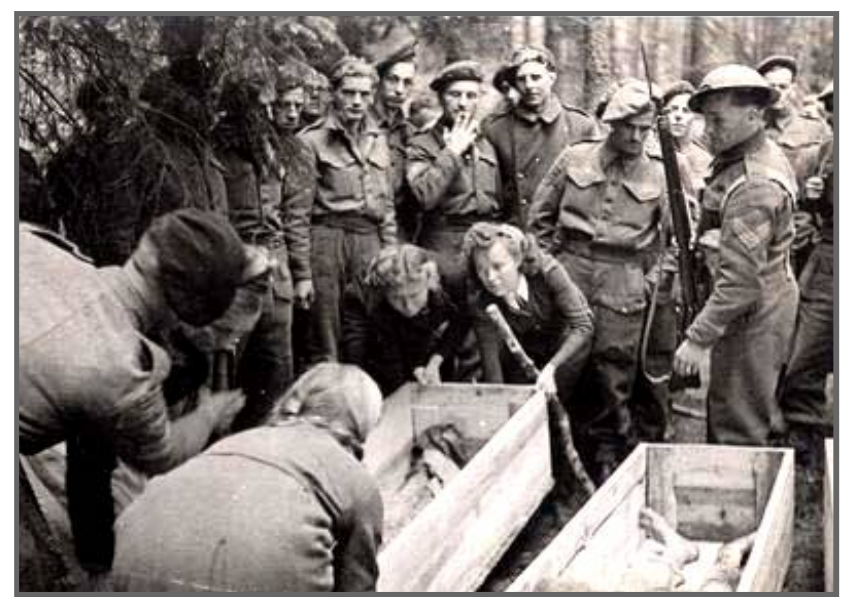

Фото 1. Жителі Дахау ведуть перепоховання в'язнів табору.

(The Holocaust Resource CenterYad Vashem, the World Holocaust Remembrance Center. URL: http://www.yadvashem.org/yv/en/holocaust/ resource_center/item.asp)

Практика залучення німецьких цивільних осіб із сусідніх міст до поховальних робіт у концентраційних таборах була започаткована генералом У. Уолкером, який таким чином покарав керівництво м. Ордруф, змусивши відвідати трудовий табір після того, як його було звільнено американськими військами 4 квітня 1945 р. Після свого візиту мер та його дружина від побаченого покінчили життя самогубством. За словами американського документаліста П. Відена, у праці "Гітлерівський вірус" описано, що "...деякі з мешканців Дахау, яких змушували дивитися на трупи, втрачали свідомість, деякі плакали і хитали головою. Більшість із них відводили очі, прагнучи не дивитися на жахливу картину і шепотячи: "Неймовірно!", інші з подивом обговорювали фракт голодування у таборі, оскільки городяни регулярно приносили ув'язненим харчові пайки" [Цит. за: Бонвеч, 2017: 99].

Наступним інструментом, який використовували союзники, стало анкетування мешканців західних зон окупації. Відповіді на 133 питання в британській та 131 - в американській зонах допомогли створити уявлення про особисту інкорпорованість німецького населення в нацистську систему. Спеціально акцентувалося покарання реальним тюремним терміном або грошовим штрафом за фальшиві дані в анкеті, які до того ж мали підтверджуватися кількома свідками; і за ухилення від анкетування. Щоб запобігти спробі ухилення від анке- тування, влада вдавалася до найефективнішого в післявоєнний час засобу: продуктова картка видавалася лише після пред'явлення квитанції, яка підтверджувала заповнення анкети в ратуші. Наявність квитанції про проходження анкетування відкривала вільний шлях і щодо реєстрації в населеному пункті, оренди житла та працевлаштування до установи або на приватне підприємство.

Попри це, нещирість опитуваних, кругова порука й корупція, коли виправдовувальні документи купувалися за шматок м'яса, робили захід ідеологічного очищення вельми неефективним та нерозбірливим, а його результати суперечливими. "Як потрібно було в таких умовах проводити денацифрікацію німців?" - задається цілком справедливим питанням Д. Франк, автор книги "Роки нашого життя. 1945-1949", описуючи групи, до яких було віднесено кожного дорослого німця [Franck, 1980: 112]. Усе населення віднесли до однієї 3 п'яти категорій: 1 - головні винні, 2 - винні, 3 - частково винні, 4 - супутники, 5 - невинні. Головний результат визначався у підсумку тим, що більше $3 / 4$ населення тільки внесли грошовий штраф за свою участь у побудові "Великої Німеччини" і лише менше 1 \% німців на основі цих анкет отримали реальні тюремні терміни. Окрім того, швидко обробити майже 25 млн анкет (згідно з кількістю дорослих жителів у двох окупаційних зонах) було фізично важко, а затягування цього процесу ще більше озлоблювало місцеве населення та зводило нанівець значення самого анкетування [Dobbins, 2008: 124].

У контексті політики денацифікації (вина-покарання) була створена значна кількість різноманітних інституцій, які, показуючи німцям зразки демократичних імперативів, очищали суспільство від націонал-соціалізму. Так, на підставі "Закону № 104" в американській зоні були створені судові палати, що ухвалювали рішення про систематизацію й комплектування у групи всього дорослого населення країни. "Комісії з виявлення військових злочинців" складали списки прізвищ німців (таких виявилося близько 1 млн!), які по-різному були причетні до створення й підтримки нацистського правлячого режиму. Були ссрормовані спеціальні суди-трибунали (Spruchkammern), які визначали ступінь залученості осіб до злочинів нацизму. Тільки в західних зонах окупації ці суди розглянули до 1949 р. 3,6 млн справ. Крім того, у всіх чотирьох зонах військові трибунали опрацьовували справи т. зв. "простого персоналу вбивць", в основному охоронців концентраційних таборів.

Ставлення до судових процесів над особами, що працювали на нацистів або самі були ними, союзники сприймали по-різному: ще на Тегеранській, а потім на Ялтинській конференції В. Черчилль був проти судових процесів, Ф. Рузвельт зауважив, що американська громадськість наполягатиме на покараннях злочинців, а Й. Сталін уважав, що публічні судові процеси можуть стати дієвим інструментом пропаганди.

Складником денацифікації було проведення одного з перших судових процесів над нацистами. До кола звинувачених 3 примітною назвою "Автоматичний арешт" (Automatic Arrest) потрапили керівники відділів кадрів СС, гестапо, СД і штурмових загонів, незалежно від посади, керівники підрозділів таких нацистських організацій, як молодіжний гітлер'югенд, охоронці концентраційних таборів тощо. Їх загальна кількість склала в британській окупаційній зоні близько 90 тис. осіб, в американській - понад 100 тис., у радянській 120 тис. Відповідно до директив Контрольної ради со- 
юзників юрисдикція німецьких кримінальних судів спочатку обмежувалася справами внутрішнього характеру. Було проведено ряд процедур, що стосувалися подій, пов'язаних із т. зв. "римським переворотом", великим погромом євреїв "кришталевої ночі" 1938 року, організованими вбивствами психічнохворих, доносами в гестапо тощо [Haas, 1946].

Епіграфічним став Нюрнберзький процес, що виконав необхідну роз'яснювальну функцію, і в широких мас не залишилося сумнівів у військових планах і злочинній практиці верхівки керівників, особливо після оприлюднення жахливих подробиць. Тим самим потенційна міфотворчість позбулася живильного ґрунту. Нюрнберзький трибунал над нацистськими злочинцями вперше в історії усесвітнього правосуддя був заснований на апеляції не до якихось норм закону, а до природного права. Програмними стали слова американського головного обвинувача Р. Джексона в його першій промові: "Ми хочемо роз'яснити із самого початку, що не маємо наміру звинувачувати весь німецький народ. Якби націонал-соціалістичній програмі слухняно слідували широкі маси народу, не були б потрібні загони штурмовиків, гестапо і концентраційні табори для німців... І, звертаючись до підсудних: "Ви стоїте перед судом не тому, що програли війну, а тому, що ї почали" [Цит. за: Космач, 2017: 207].

Перші враження письменника Е. Кестнера, що спостерігав за подіями в Нюрнберзі, відбиті в статті "Нової газети" від 23.11.45: "Чому не проводили народи землі такі процеси вже тисячу років тому? На землі пролилося б менше крові, люди не знали б стільки страждань..." [Цит. за: Schildt, Siegfried, 2009: 79]. Згодом два автори фундаментальної праці "Нюрнберзький процес" I. Хайдекер та І. Лєєб писали про процес прозаїчніше: "...він не був трибуналом переможців; судді провели чесну роботу, яку ми, німці, тоді виконати самостійно не змогли б. Вони зуміли відмовитися від спокуси колективного покарання і тим самим допомогли мільйонам німців-супутників уникнути засудження" [Неуdecker, Leeb, 1979: 35].

У Нюрнберзі після головного процесу проводилося ще дванадцять: справи лікарів, юристів, чиновників управлінців концтаборами, справа 23 керівників промисловців "Фарбеніндустрі", керівників расистської програми, учасників військових груп знищення євреїв і політичних противників режиму, справа Круппа, чиновників міністерства закордонних справ та ін. У цілому в західних зонах перед судами пройшло 5133 особи і ухвалено 668 смертних вироків. Не всі вони були виконані, і багато засуджених відбули термін ув'язнення не повністю. Значна кількість достатньо відомих постатей уникнули суворого покарання, а родичі деяких із них стали першими політичними особами вже майбутньої ФРН. Спроби американців засудити промисловців і фрінансистів закінчилися невдачею: адвокатам вдалося виграти через слабкість доказової бази звинувачення. Проте найбільш одіозні фрігури були засуджені.

Денацифрікація передбачала необхідність не пускати на керівні посади людей з СС (0,5 млн осіб) і НСДАП (8 млн членів). У результаті виникла парадоксальна ситуація: були покарані дрібні нацисти, а більш значущі 3 минулим благополучно дочекалися 1948 р., коли денацифікація була фрактично припинена. Це сталося тому, що розгляд важливих справ постійно відтерміновувався, а несуттєві проходили як супутні з винесенням швидкого судового рішення в перші роки. Це породжувало в суспільстві соціальну несправедливість, на- слідками якої стали різного роду махінації та маніпулювання суспільною думкою і нарешті - закріплення в офріційному дискурсі неправдивої інформації.

Проведення денацифікації вимагало багато часу, оскільки понад 4 млн осіб чекали вердикту судів. Тому США вирішили певним чином скоротити тривалість цього процесу і пришвидшити досягнення певного результату. У липні 1946 року за ініціативою генерала Л. Клея відбулася амністія молоді: ті, хто народився після першого січня 1919 р. і не потрапив до списків активних нацистів і військових злочинців, звільнялися від проходження денацифікації [Dobbins, 2008: 142].

Через повільну швидкість діловодства багато сімей опинялися у скрутному матеріальному становищі у зв'язку із забороною працювати до отримання свідоцтва про денацифікацію (т. зв. "Чистий законопроект" (Persilschein)). Закладена в "Закон № 104" презумпція вини провокувала лицемірство, кругову поруку та спроби забілити провину. Нерідко свідки під присягою засвідчували бездоганну політичну поведінку обвинувачуваного або його спосіб життя справжнього християнина, а це, у свою чергу, перетворювало процедуру на фрарс, коли деякі нацисти шантажували один одного: "Якщо ти скажеш що-небудь про мене, тоді я розповім про тебе". У результаті доносів, пліток, інтриг закоренілі нацисти інколи поставали новими демократами (особливо в британській зоні), а "супутники" режиму повинні були нести відповідальність тільки тому, що вони не бажали бути такими гнучкими пристосуванцями. Найрадикальніші критики програми стверджували, що "...суб'єктивно процес денацифрікації перешкоджав багатьом німцям визнати себе більш-менш важливою частиною механізму нацистської тоталітарної держави, без якої ніколи б не виник Третій рейх" [Franck, 1980: 105].

На початку 1946 р. стало зрозуміло, що внаслідок надмірно жорстких і схематичних критеріїв недопущення колишніх членів партії до ключових посад у деяких районах, особливо в американській зоні, настав хаос в управлінні й економіці через брак компетентних кадрів. Союзники, у першу чергу американці, зрозуміли, що військова диктатура себе віджила й необхідні зміни. Крім того, у населення початкова підтримка змінилася незадоволеністю практикою денацифікації в цілому (акцентувалася колективна, а не індивідуальна провина) i, зокрема, анкетою. Хоча британці й французи діяли обачніше, але і в їхніх зонах ця процедура затягувалася. Отже, на хвилі суспільної критики процесу, результатів та наслідків денацифікації колишні нацисти знову поверталися до займаних ними раніше посад або ж тих, що більш-менш відповідали їх попередньому місцю роботи. Зазвичай вони були номінальними нацистами, а їхня незначна участь у злочинній діяльності нацистської партії була виправдана німецькими судами [Бойко, Іванов, 2018]. Показовим у цьому став процес над "улюбленою" режисеркою А. Гітлера Ленні Ріфеншталь. Ії кілька разів заарештовували, але вже 3 червня 1945 р. вона була визнана остаточно невинною і прожила довге життя без спокути за свою діяльність у роки Третього рейху.

Указані заходи, поєднані з поверненням до Німеччини військовополонених, біженців, перешкоджали своєчасному завершенню програми. А якщо врахувати, що повоєнна ситуація засвідчила брак достатньої кількості суддів, слідчих, прокурорів зі знанням німецької мови, здатних ефективно й швидко здійснити розгляд тисяч судових справ, а також те, що окупаційна 
влада часто заарештовувала підозрюваних без відповідного дозволу, то ставлення найлояльніших та найдемократичніших антинацистів могло підвести межу під співпрацею двох систем.

У радянській зоні до денацифікації підійшли поіншому, але не менш серйозно. Для засуджених було організовано десять спецтаборів, у яких знаходилося 150 тис. ув'язнених. Тут, на відміну від практики західних зон, колишніх есесівців, штурмовиків та охоронний персонал тримали в таборах для військовополонених із подальшим відправленням на примусові роботи в Радянський Союз. Значно поблажливіше поставилися до рядових членів партії, які після закінчення війни принципово отримали можливість інтеграції в нове суспільство. Зведення рахунків із минулим, у якому із самого початку брали участь німці, націлювалося на майбутнє країни без промисловців і великих землевласників, які привели Гітлера до влади, із робітниками на керівних посадах. Уважається, що денацифікація в радянській зоні стала знаком розриву з нацистським минулим. У серпні 1947 р. денацифікація фактично припинилася, у лютому 1948 р. її офріційно оголосили завершеною.

На східному березі Ельби послідовно очищалися органи управління, юстиції, середня і вища школи, звідки звільнили в 1945-48 рр. приблизно півмільйона колишніх членів нацистської партії - 80 \% усіх суддів і половину вчителів. Найрадикальнішого чищення зазнали органи юстиції: до суду взагалі жодного колишнього юриста не допустили, лише "перевірених" осіб. У жовтні 1945 р. відкрилося нове міністерство юстиції, а за судовою реформою 1946 р. переважна більшість суддів і прокурорів були замінені народними суддями, які, як правило, не мали юридичної підготовки [Voigt, 1948: 47]

Денацифікацію як публічний процес очищення пройшла освітня система в цілому. У всіх зонах окупації фракультети теології, медицини і природничих наук були швидко укомплектовані викладацьким складом і охочими вчитися студентами. Зокрема, літніми викладачами були укомплектовані і юридичні факультети. Крім того, в університетах були організовані абсолютно нові факультети політології, які пізніше показали себе найкращим інструментом у "перевихованні" німців. Викладачами цих факультетів в основному стали колишні емігранти. Для інших фракультетів емігрантів катастрофічно не вистачало, тому довелося брати на роботу тих, хто зміг довести, що в період нацистського режиму був у стані "внутрішньої еміграції" або хоча б аполітичним [Кун, 2007: 48]

Учителів середніх шкіл у всіх окупаційних зонах було звільнено, а освітні програми були кардинально перероблені. Цей процес досить довго тривав і призвів до того, що навчання не розпочиналося, не відкривалися НЗ. I тільки після залучення до навчального процесу пенсіонерів і т. зв. помічників учителів - в основному студентів - змогли забрати дітей з вулиць. Значна увага приділялася конфесійному релігійному вихованню та освіті, тому що церква як соціальний інститут виявилася найбільш готовою до відновлення освітньої системи. До 1949 р. окупаційна влада оцінювала і спочатку масово піддавала цензурі книги та підручники, підготовлені німцями. Проте впродовж освітньої денацифікації цифри динамічно змінювалися: у 1947 р. кількість відхилених рукописів гуманітарної тематики знизилася з $19 \%$ до $6 \%$, а серед підручників історії - 3 $50 \%$ до $17 \%$.

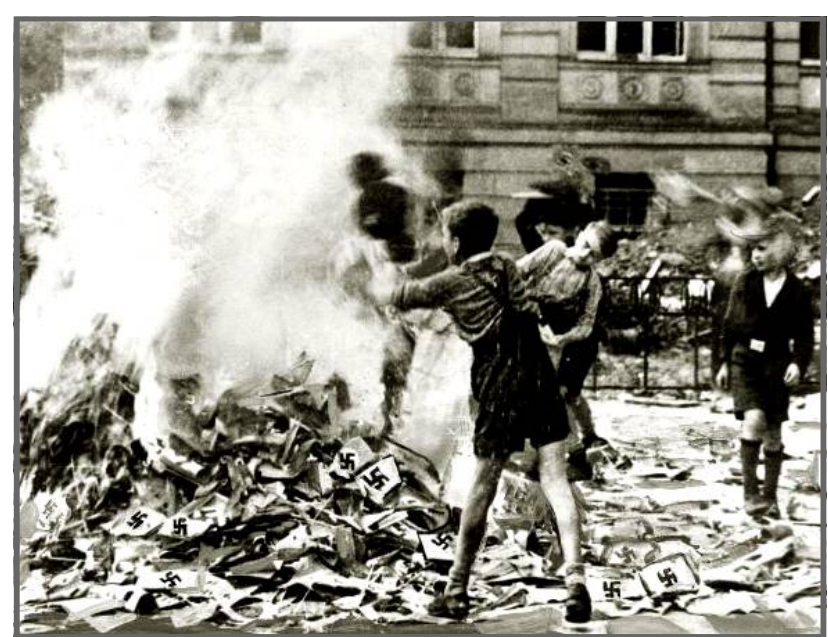

Фото 2. Діти спалюють нацистські книги та свастику в Кельні.

(German civilians brought to see the camps. URL: https:/ /www.gettyimages. de/detail/nachrichtenfoto/red-armysoldiers-passing-a-burning-house-owned-by-anachrichtenfoto/542887319)

Головним об'єктом змін стала історія, оскільки потрібно було змінити як інтерпретацію всієї довоєнної історії, так і переосмислити далеке минуле, що заклало фундамент сьогодення. У дискурс історії вводилася нова символічна картина із зміною оцінок не тільки довоєнного минулого, але й більш віддалених подій. Наприклад, Селянська війна 1524 - 1525 рр. почала вперше трактуватися як перші кроки Німеччини в боротьбі за демократію. Два інші символи в цьому демократичному русі - Конституція 1848 р. і Веймарська республіка - продовжили процес становлення демократії. 1945 рік називався завершальною ланкою в становлення демократії в Німеччині [Почепцов, 2015].

Велике значення надавалося організованому дозвіллю та впливу на суспільну свідомість через ЗМІ. Американці серйозно займалися розвитком демократичного та ліберального театру, музики, образотворчого мистецтва, кіно, літератури. Німецьке населення повинно було усвідомити свою відповідальність за скоєне й визнати вину. Для цього публікувалися пропагандистські плакати із зображенням злочинів війни та надписами: "Це ваша провина!", "Ви винні в цьому!", відбувся показ першого німецького художнього фрільму 1947 року В. Штаудте "Убивці серед нас". У перші місяці після капітуляції демонстрували "добровільно-примусовим" глядачам документальний фільм про концентраційні табори "Жорна смерті" (Death Mills). Показ фільму проводився 3 визначеною просвітницько-трудовою метою. Наприклад, у радянській і американській зонах окупації адміністрація видавала картки на продукти тільки тим, хто мав відмітку про відвідування кінозалу [Davidson, 1959: 79].

Щоб об'єднати суспільство, упроваджувалася ідея локального патріотизму, почали з'являтися громадські організації культурного спрямування, які не лише допомагали інтелігенції пристосуватися до нових культурних цінностей, а й склали основу новоствореного громадянського суспільства. Упродовж перших чотирьох років було створено 25 Американських інформаційних центрів (Amerika Haus) та їх фріліалів (читальні зали) у невеликих містах [Жаронкина, 2015: 121].

Якийсь час радіостанції працювали під цензурою

СХІД № 4 (156) липень-серпень 2018 р. 
американців і британців. Вони ж видавали ліцензії для роботи німецьким журналістам. Ліцензії на видання німецьких газет видавалися не фізичним особам, а партійним і громадським організаціям в т. ч. й у Східній Німеччині. Американці уважно стежили за публікаціями в пресі, висуваючи категоричною умовою об'єктивне висвітлення подій і жорстку межу між новинами та думками, оцінками. У коментарях і висновках обов'язково мав бути плюралізм [Haas, 1946].

Після припинення випуску армійських газет німецькою мовою американці заснували "Нову газету", американську газету для німців, що стала популярною: при накладі 2,5 млн екземплярів у той важкий час не всі охочі могли офрормити на неї передплату. Як було оголошено, "... Німеччина зобов'язана перетворитися на країну мирних жителів, у якій кожен дістане можливість проявити свою ініціативу... Фізичну демілітаризацію ми доведемо до кінця, але вона одна не створить гарантії, що Німеччина в майбутньому знову не втягне світ у війну. Для всіх народів Землі війна сама по собі щось аморальне, але німці повинні бути перевиховані для розуміння цієї самоочевидної істини. Також і в цьому аспекті німиям належить самим викоренити небезпечні паростки своєї фрілософрії" [Schildt, Siegfried, 2009: 138].

Керівні посади (особливо що стосується мас-медіа) обіймали реемігранти - інтелігенція та політична еліта, що залишила Німеччину з приходом до влади Гітлера. Щоправда, спершу реемігранти сприймались місцевими насторожено, але все ж це дозволило в майбутньому сформувати національні органи влади. Значна кількість творів імпортувалася із США й перекладалася німецькою. Але й німецькі письменники, філософи, музиканти, художники отримували підтримку, у тому числі й матеріальну. У короткий час народилися близько 150 суспільно-політичних журналів: "Франкфуртські записки", "Заклик", "Захід і Схід", "Зміна" та інші. Вони стали форумом, на якому нація, що пережила розгром, аналізувала й обговорювала актуальні проблеми. Ця періодика менше, ніж газети, страждала від військової цензури і мала тому більшу свободу слова, що виявилося своєрідною оазою свободи думок. Головною прикметою післявоєнної німецької літератури стала її насиченість духом часу, увага до політичних і соціальних проблем і відвертість в оцінках недавнього минулого країни і поточних подій [Бондарь, 2017: 62]. Німецький письменник-емігрант Генріх Белль, нобелівські лауреати Томас Манн та Гюнтер Грасс проголошували, що: "...завдання німецького письменника, як і будь-якого іншого у всі часи - бути суддею і дороговказною зіркою народу, особливо в часи, коли йому загрожує небезпека впасти в апатію і відчай... Письменник своїм твором дає приклад непохитності і внутрішньої свободи" [Haas, 1946]. Відомі німецькі історики М. Мессершмідт, Р. Юбершер, В. Ветте, Х. Нольте, В. Бенц, В. Якобмайер, П. Ян, А. Хільгрубер, Ю. Габермас і багато інших неупереджено висвітлювали реалії війни, розв'язаної німецьким нацизмом.

Ефективність будь-якої справи посилюється 3 реалізацією міжособистісних стосунків. А якщо їх офіційно не існувало? В американській і британській арміях у перші післявоєнні місяці діяла заборона на неформальні контакти з німецьким населенням (у радянській зоні такого фракту не було) і спілкування майже не спостерігалося. У директивах американським військам указувалося: "Не проявляй співчуття, навіть побачивши дітей, що переминаються з ноги на ногу на хо- лоді біля входу в армійську їдальню; вони дуже ввічливі або сором'язливі, щоб жебракувати, але в очах у них голод... Люди похилого віку з ручними візками, юні дівчата, що мерзнуть на холодному вітрі в тонких платтях... Ти скажеш, що вони не нацисти... Ми не повинні в жодному разі вірити німцям: після 12-ти років життя в геббельсівскій фрабриці брехні будь-який із них став експертом у брехні, напівправді і підлих натяках, які він наговорить, щоб утертися в довіру й добитися свого. Німець знає всю брехню напам'ять..." [Directive to the Commander..., 1950: 37].

Прецедентом зворотної дії в цей час стала організація першого клубу німецько-американської дружби "Bad Kissingen Cosmopolitan Club". Але оскільки організація сумісного з німцями клубу суперечила закону, він був незабаром ліквідований, а капітан Р. Поттер, який його заснував, усунений з посади. Переконаний у правильності своїх дій, капітан зажадав розслідування справи військовим судом. Утрутився головнокомандувач генерал Л. Клей, який викликав до себе упертого капітана i, замість того щоб віддати його під суд, дав завдання організувати подібні клуби дружби в усій американській зоні, що було демонстративним порушенням існуючого порядку, але відповідало відчуттям більшості американців. Майбутнє підтвердило правоту Клея й Поттера: клуби стали для багатьох німців школою "прикладної демократії" [Кун, 2007: 47].

Тому вже наприкінці літа 1945 р. командування союзних військ змінило тактику і дозволило "... вступати в розмови з німцями на вулицях і в суспільних місцях. Це дасть ... можливість встановити контакти з населенням і краще розуміти проблеми людей". А перелом у взаєминах американців і німців відбувся в 1946 р. після "Мови надії" держсекретаря Дж. Ф. Бірнса, який оголосив, що "Сполучені Штати не хочуть збільшувати страждань Німеччини, які їй заподіяв Гітлер, почавши війну. Американський народ хоче допомогти німецькому народу знайти своє місце серед вільних $i$ миролюбних націй миру". Нормалізації відносин сприяло також зняття заборони на шлюби між солдатами армії союзників і німцями; в англійській зоні до травня 1947 р. надійшло 3600 заяв від солдатів із проханням дозволити шлюб з німкенею [Schullze, 1948].

Незважаючи на сурові вироки, заходи відображали все ж таки м'яку денацифікацію, оскільки з 13,2 млн перевірених німців тільки 613 тис. осіб були визнані певною мірою винними в причетності до злочинів нацизму, а заарештовано 270 тис. осіб із нацистським минулим.

\section{Висновок}

Інтеграція незліченної кількості супутників у післявоєнне суспільство - ось ціна плати за політичну стабілізацію. Повторна нацифікація народу не відбулася завдяки бажанню більшості пристосуватися до нової ситуації і працювати, отримуючи за свою працю справедливу оплату. Перші післявоєнні роки - роки несприйняття та опору. Був і саботаж, і помилки, і корупція. Але з 1950-х років відбувся остаточний перелом. Нацизм був вигнаний з більшої частини західного німецького суспільства, і для того, щоб диктатура не змогла відродитися, були розроблені дієві механізми. Таким чином, ми бачимо, що навіть у німецькому науковому співтоваристві не розглядається теза про покаральний характер денацифікації і висувається гіпотеза про те, що переможці ставили перед собою мету трансформувати німецьке суспільство, не караючи його. 


\section{ЛІТЕРАТУРА}

1. Бойко М., Іванов О. Проведення політики денацифікації Німеччини в Американській зоні окупації (1945-1949рр.). Європейські історичні студії. 2018. № 10. С. 63-81. URL: http:// eustudies.history.knu.ua/myhajlo-bojko-oleksandr-ivanovprovedennya-polityky-denatsyfikatsiyi-nimechchyny-vamerykanskij-zoni-okupatsiyi-1945-1949-rr.pdf (дата звернення: 11.08.2018).

2. Бонвеч Б. Двойное преодоление тоталитарного прошлого в Германии 1945 и 1990 годов. Преодоление прошлого в Германии и России: опыт и уроки на будущее (памяти профессора А. И. Борозняка): материалы Международной научной конф. (16-17 февраля 2017 г., Липецк). Липецк: ЛГПУ имени П. П. Семенова-Тян-Шанского, 2017. С. 96-105.

3. Бондарь И. А. Денацификация Германии в творчестве немецких писателей XX века. Известия высших учебных заведений. Проблемы полиграфии и издательского дела. Москва: Московский государственный университет печати имени Ивана Фёдорова, 2017. № 2. С. 59-68.

4. Жаронкина Е. А. Политика американской военной администрации по возрождению культурной и духовной жизни Германии (1945-1949 гг.). Вестник Кемеровского государственного университета. 2015. № 3 (63). Т. 2. С. 119-123.

5. Космач В. А. Германия и германский вопрос в 19451949 гг.: страницы истории и оценки историков: монография. Витебск: ВГУ имени П. М. Машерова, 2017. 338 с.

6. Кун Г. Возвращение из преисподней: денацификация послевоенной Германии. Историк и художник. 2007. № 12. C. 41-50.

7. Почепцов Г. Послевоенная денацификация Германии как контрпропаганда. URL: https://psyfactor.org/lib/ denazification2.htm (дата звернення: 02.08.2018).
8. Сиваченко І. Нюрнберг як місце німецької колективної пам'яті про другу світову війну. Український історичний збірник. 2010. Вип. 13. С. 245-251.

9. Directive to the Commander in Chief of the U.S. Occupation Forces (JCS 1067) (April 1945). United States Department of State, Germany 1947-1949: The Story in Documents. Washington, DC. U.S. Government Printing Office, 1950. P. 31-39.

10. Dobbins J. After the war. Nation-building from FDR to George W. Bush. Santa Monica, 2008. 351 p.

11. Davidson E. The death and life of Germany: An Account of the American Occupation. New York: Alfred Knopf, 1959. 456 p.

12. Franck D. Jahre unseres Lebens. 1945-1949. Reinbek bei Hamburg, Rowohlt Taschenbuch Verlag GmbH, 1980. $198 \mathrm{~s}$.

13. Heydecker J., Leeb J. Der Nürnberger Prozess. Köln: Kiepenheuer, 1979. 406 s.

14. Haas S. Denazifizierung. Gesetz und Verfahren. Heidelberg: Adolf Rausch Verlag, 1946. 88 s. URL: https:// dirkdeklein.net/2017/10/02/denazification-a-small-price-to-pay-fora-genocide (дата звернення: 30.07.2018)

15. Schildt A., Siegfried D. Deutsche Kulturgeschichte: die Bundesrepublik - 1945-bis zur Gegenwart. Bonn: Bundeszentrale für politische Bildung, 2009. $696 \mathrm{~s}$.

16. Schullze E. Gesetz zur Befreiung von Nationalsozialismus und Militarismus von 1946. München: Biederstein, 1948. 427 s. URL: http://www.rothenburg-unterm-hakenkreuz.de/ entnazifizierung-3-grundlage-war-das-gesetz-nr-104-zurbefreiung-von-nationalsozialismus-und-militarismus-von-1946 (дата звернення: 04.08.2018).

17. Voigt T. R. Denazification in Soviet-occupied Germany. Brandenburg, 1945-1948. Cambridge: Harvard University Press, 2000. 336 p.

Kuprii Tetiana,

PhD in Historical Sciences, Assistant professor Department of Philosophy,

Borys Grinchenko Kyiv University, Kyiv

\section{SUCCESSES AND PROBLEMS OF "RE-EDUCATION": TO THE 70th ANNIVERSARY OF COMPLETION OF DENAZIFICATION OF GERMANY}

In the article the various social aspects of policy of denazification of Germany are probed in 1945-1948, which were stopped up in basis of spiritual and cultural revival of the post-war state. Basic measures and actions of organs of occupation power of allies are examined on "re-education" of Germans after the crash of national socialism and blowing off political and ideological bases of German society of in general.

On the basis of analysis of accessible types of sources the mechanisms of democratization of German society, their successes and failures, are reflected in realization. The social aspects of policy of denazification are analyzed as to the process of ideological transformation of nation. Investigational factors of influence on forming of new socio-cultural reality of post-war Germany. At the use of information of cross-cultural researches the integral frame of society of new post-nationalist socialist Western European country is represented in the conditions of occupation.

It was planned to carry out returning to traditions of democracy by antinazi Germans, catholic and lutheran church, educational establishments, literature, cinema, music, theater on a background adjusting of social and household life of ordinary citizen. The regeneration of Germany must was be carried out the method of ideological transformation, licensing and control of Media.

Implement of western democratic catchers in Germany was inculcated unevenly and inconsistently, what counteraction of local population was as a result of. And only after the awareness of occupation power, in particular western areas, minimum intervention from administrations, close cooperation between even subjects, and also gradual transmission to Germans of responsibility for the results of denazification, there was possibility of revival of public life without deepening and complication contradictions which overcame a country in the first post-war years. It allowed solve of that time problems and in a new decade to enter on principles of the realized democracy.

Keywords: denazification; "cleaning"; nazism; of occupation power; Supervisory council of allies.

\section{REFERENCES}

1. Boyko, M. \& Ivanov, O., 2018. Realization politicians of denazification of Germany in the American area of occupation (1945-1949). European historical studios. № 10. C. 63-81. Available at: http://eustudies.history.knu.ua/myhajlo-bojko-oleksandr-ivanov-provedennyapolityky-denatsyfikatsiyi-nimechchyny-v-amerykanskij-zoni-okupatsiyi-1945-1949-rr.pdf (Accessed: 11.08.2018). (ukr).

\section{СХІД № 4 (156) липень-серпень 2018 р.}


2. Bonvec, B., 2017. Double overcoming of the totalitarian past in Germany in 1945 and 1990. Overcoming the past in Germany and Russia: experience and lessons for the future (in memory of Professor A.I. Boroznyak): materials of the International Scientific Conference (February 16-17, 2017, Lipetsk). Lipetsk: LSPU named after P.P. Semenov-Tian-Shansky. P. 96-105. (rus).

3. Bondar, I. A., 2017. Denazification of Germany in the works of German writers of the XX century. News of higher educational institutions. Problems of polygraphy and publishing. Moscow: Moscow State University of Printing named after Ivan Fyodorov. № 2. P. 59-68. (rus).

4. Zharonkina, E. A., 2015. The policy of the American military administration on the revival of the cultural and spiritual life of Germany (1945-1949). Herald of the Kemerovo State University. № 3 (63). V.2. P. 119-123. (rus).

5. Kosmach, V.A., 2017. Germany and the German question in 1945-1949: pages of history and evaluation of historians: monograph. Vitebsk: VGU named after P.M. Masherov. 338 p. (rus).

6. Kuhn, G., 2017. Return from the Underworld: the denationalization of post-war Germany. A historian and an artist. № 12. P.4150. (rus).

7. Pocheptsov G. Post-war denationalization of Germany as counter propaganda. Available at: https://psyfactor.org/lib/ denazification2.htm (Accessed: 02.08.2018). (rus).

8. Sivachenko, I., 2010. Nurnberg as the place of German collective memory of the Second World War. Ukrainian Historical Collection. V.13. P. 245-251. (ukr).

9. Directive to the Commander in Chief of the U.S. Occupation Forces (JCS 1067) (April 1945). 1950. United States Department of State, Germany 1947-1949: The Story in Documents. Washington, DC. U.S. Government Printing Office. P. 31-39. (eng).

10. Dobbins, J., 2008. After the war. Nation-building from FDR to George W. Bush. Santa Monica. 351 p. (eng). (eng).

11. Davidson, E., 1951. The death and life of Germany: An Account of the American Occupation. New York. Alfred Knopf. 456 p.

12. Franck, D., 1980. Jahre unseres Lebens. 1945-1949. Reinbek bei Hamburg, Rowohlt Taschenbuch Verlag GmbH. 198 s. (ger).

13. Heydecker, J., Leeb J., 1979. Der Nürnberger Prozess. Köln: Kiepenheuer, 406 s. (ger).

14. Haas, S., 1946. Denazifizierung. Gesetz und Verfahren. Heidelberg. Adolf Rausch Verlag. 88 s. Available at: https://dirkdeklein.net/ 2017/10/02/denazification-a-small-price-to-pay-for-a-genocide (Accessed: 30.07.2018) (ger).

15. Schildt, A. \& Siegfried, D., 2009. Deutsche Kulturgeschichte: die Bundesrepublik - 1945-bis zur Gegenwart. Bonn. Bundeszentrale für politische Bildung, $696 \mathrm{~s}$. (ger).

16. Schullze, E., 1948. Gesetz zur Befreiung von Nationalsozialismus und Militarismus von 1946. München: Biederstein. 427 s. Available at: http://www.rothenburg-unterm-hakenkreuz.de/entnazifizierung-3-grundlage-war-das-gesetz-nr-104-zur-befreiung-vonnationalsozialismus-und-militarismus-von-1946 (Accessed: 04.08.2018) (ger).

17. Voigt, T. R., 2000. Denazification in Soviet-occupied Germany. Brandenburg, 1945-1948. Cambridge: Harvard University Press, 336 p. (eng).

(C) Купрій Тетяна

Надійшла до редакції 12.08.2018 